\title{
Multiyear Evaluation of the Durability of the Resistance Conferred by Ma and RMia Genes to Meloidogyne incognita in Prunus Under Controlled Conditions
}

\author{
Samira Khallouk, Roger Voisin, Ulysse Portier, Joël Polidori, Cyril Van Ghelder, and Daniel Esmenjaud
}

All authors: INRA, UMR1355 ISA; UNS UMR ISA; CNRS UMR7254 ISA F-06903 Sophia Antipolis, France. Accepted for publication 14 February 2013.

\begin{abstract}
Khallouk, S. Voisin, R., Portier, U., Polidori, J., Van Ghelder, C., and Esmenjaud, D. 2013. Multiyear evaluation of the durability of the resistance conferred by Ma and RMia genes to Meloidogyne incognita in Prunus under controlled conditions. Phytopathology 103:833-840.

Root-knot nematodes (RKNs) (Meloidogyne spp.) are highly polyphagous pests that parasitize Prunus crops in Mediterranean climates. Breeding for RKN-resistant Prunus cultivars, as an alternative to the nowbanned use of nematicides, is a real challenge, because the perennial nature of these trees increases the risk of resistance breakdown. The $M a$ plum resistance $(R)$ gene, with a complete spectrum, and the RMia peach $R$ gene, with a more restricted spectrum, both provide total control of Meloidogyne incognita, the model parthenogenetic species of the genus and the most important RKN in terms of economic losses. We investigated the durability of the resistance to this nematode conferred by these genes, comparing the results obtained with those for the tomato $M i-1$ reference gene. In multiyear experiments, we applied a high and continuous nematode inoculum pressure by cultivating nematode-infested susceptible

genes, or with resistant tomato plants carrying the $M i-1$ gene. Suitable conditions for Prunus development were achieved by carrying out the studies in a glasshouse, in controlled conditions allowing a short winter leaf fall and dormancy. We first assessed the plum accession 'P.2175', which is heterozygous for the $M a$ gene, in two successive 2-year evaluations, for resistance to two $M$. incognita isolates. Whatever the isolate used, no nematodes reproducing on P.2175 were detected, whereas galls and nematodes reproducing on tomato plants carrying $M i-1$ were observed. In a second experiment with the most aggressive isolate, interspecific fullsib material $(\mathrm{P} .2175 \times$ ['Garfi' almond $\times$ 'Nemared' peach]), carrying either Ma or RMia (from Nemared) or both (in the heterozygous state) or neither of these genes, was evaluated for 4 years. No virulent nematodes developed on Prunus spp. carrying $R$ genes, whereas galling and virulent individuals were observed on $M i$ - 1 -resistant tomato plants. Thus, the resistance to $M$. incognita conferred by $M a$ in Prunus material in both a pure-plum and an interspecific genetic background, or by RMia in an interspecific background, appears to be durable, highlighting the value of these two genes for the creation of Prunus rootstock material.
\end{abstract} tomato plants with either Prunus accessions carrying Ma or RMia $R$
Root-knot nematodes (RKNs) (Meloidogyne spp.) are highly polyphagous biotrophic pests that attack most vegetable, fruit, and ornamental crops in Mediterranean and hot climates $(1,47)$. The RKN causing the greatest economic losses are Meloidogyne incognita, $M$. javanica, and $M$. arenaria, which are highly polyphagous and reproduce through mitotic parthenogenesis. Nematicides are highly toxic and their use is increasingly prohibited. An environmentally friendly alternative is urgently required, and the breeding of RKN-resistant $(\mathrm{R})$ cultivars is a promising approach. Most of the few RKN resistance $(R)$ genes identified to date come from annuals (55), and most studies on resistance genetics have focused on the model gene $M i-1$ from tomato (53, 54), the first RKN gene to be cloned (38). However, three major $R$ genes have been identified and mapped in perennial Prunus spp.: the RMia gene from peach (Prunus persica) $(12,16,35)$, the $R M j a$ gene from almond $(P$. dulcis) $(32,50)$, and the $M a$ gene from Myrobalan plum (P. cerasifera) $(12,14,16,21,34)$.

The breakdown of plant resistance by virulent populations is a limitation of genetic control strategies for crop pests and diseases. Identifying the genes involved in the $\mathrm{R}$ sources and characterizing their biological features is an essential step for the deployment of durable resistance $(6,8,9,29)$. The two key features of resistance are its spectrum (horizontal component) and strength (vertical

Corresponding author: D. Esmenjaud;

E-mail address: Daniel.Esmenjaud@sophia.inra.fr

http://dx.doi.org/10.1094/PHYTO-09-12-0228-R

(C) 2013 The American Phytopathological Society component). The possible adaptation of parthenogenetic populations of RKNs to the resistance conferred by the $M i-1$ gene has raised concern about the mechanisms underlying the plant-nematode interaction $(6,15,44)$. The recently cloned $M a$ gene (13) triggers a hypersensitive-like reaction characterized by the complete absence of galls $(30,51)$. This gene controls the predominant species $M$. arenaria, $M$. incognita, and $M$. javanica (34), together with the emergent and highly invasive RKN $M$. enterolobii $(7,45,56)$, formerly known as M. mayaguensis (42), which is not controlled by the Mi-1 gene (3-5,31). This Prunus gene also controls the minor species $M$. hispanica $(22,27)$ and the southeastern U.S. species M. floridensis (26), both of which were originally isolated from Prunus crops. M. floridensis is often referred to as the "peach" RKN because it was first detected on this stone fruit crop and has been shown to multiply on the 'Nemaguard' and 'Nemared' RKN resistance sources $(11,23,40,43)$.

The resistance conferred by the $M a$ gene is both full spectrum and strong. This strong level of resistance is not affected by high temperatures (20), unlike the peach rootstock Nemared carrying the RMia gene (52). This key feature has been demonstrated in genetic studies based on an evaluation procedure involving the application of high and continuous inoculum pressure $(19,20)$. Both these key properties are essential for success in the construction of rootstocks with durable RKN resistance. With this in mind, current breeding strategies are based on the pyramiding of several Prunus $R$ genes with, as a first step, the combination of the Ma and RMia genes in interspecific rootstocks (18). Breeding for RKN in long-term programs is a real challenge for any peren- 
nial species, because the longevity of the plant prolongs the plant-nematode interaction, greatly increasing the risk of resistance breakdown. Predictive strategies, based on both the efficacy and resistance spectrum of the genes used, are being implemented.

We describe here the use of a method providing a high-level and continuous inoculum pressure for multiyear evaluations to study the durability of the resistance to $M$. incognita conferred by the Ma and RMia genes, with a comparison of the results obtained with those for the $M i-1$ reference gene from tomato.

\section{MATERIALS AND METHODS}

Plant material and RKN resistance status. Evaluations were performed on Prunus accessions, with tomato cultivars used as the reference material for RKN resistance (Table 1). In experiment 1, the Prunus material evaluated consisted of the pure Myrobalan plum (P. cerasifera Ehrh, section Euprunus) accession 'P.2175', carrying the $M a$ gene in the heterozygous state (the recently cloned Mal allele) (13). In experiment 2, interspecific hybrids of the three-way plum $\times$ almond $(P$. dulcis (Miller) D. A. Webb) $\times$ peach $(P$. persica $($ L. $)$ Batsch) type from the P.2175 plum $\times$ ('Garfi' almond $\times$ Nemared peach $)_{22}$ progeny created at INRAUREF (Villenave d'Ornon, France) were used (24) (Fig. 1). These hybrids, obtained by crossing P.2175 and (Garfi $\times$ Nemared) $)_{22}$ (heterozygous for the RMia gene [RMia ${ }_{N e m}$ allele]), display segregation for each of the RKN $R$ gene loci and generate individuals carrying one of the four possible combinations of the two genes: $M a+$ RMia, Ma alone, RMia alone, or neither (Fig. 1). The representatives of each of these four classes of individuals were as follows: (P.2175 $\times$ GN22) ${ }_{43}$ (carrying Ma + RMia); $(\mathrm{P} .2175 \times$ GN22) ${ }_{78}$ (carrying Ma); $(\mathrm{P} .2175 \times \mathrm{GN} 22)_{66}$ (carrying RMia); and $(\mathrm{P} .2175 \times \mathrm{GN} 22)_{81}$ (carrying no $R$ gene) .

Two tomato cultivars were used: the RKN-susceptible (S) 'St Pierre' and the RKN-R 'Piersol', carrying the Mi-l gene (33), which is considered almost isogenic to St Pierre.

Nematode material. The species $M$. incognita was used in this study, because it is the RKN with the greatest economic impact and is considered the reference parthenogenetic species of Meloidogyne (1). Two isolates from this RKN species were used: 'Kursk' from Russia and 'Morelos' from Mexico (10). Both isolates were reared from a single egg mass. These isolates, avirulent with respect to the $M i-1 R$ gene, were maintained on the RKN-S tomato (Lycopersicon esculentum Mill.) St. Pierre. The identity of both isolates, at the species level, was checked once yearly, by determining isoesterase phenotype (28). Both isolates were used in experiment 1 and Morelos, the more aggressive isolate, was used in experiment 2 (Table 1). The nematode inocula used in all experiments were multiplied on tomato St Pierre without prior selection on Prunus plants or on tomato Piersol.

Design of multiyear experiments. The general scheme of the two experiments is displayed in Figure 2. Experiment 1 lasted 4 years, divided into two successive 2 -year subexperiments, 1a and $1 \mathrm{~b}$ (Table 1). Subexperiment $1 \mathrm{~b}$ was set up with new Prunus and tomato plants in the same conditions as subexperiment 1a. Experiment 2 also lasted 4 years but was conducted as a single experiment (Table 1).

Application of a high level of continuous inoculum pressure. Prunus material was propagated at INRA Villenave d'Ornon (France) from softwood cuttings sampled from adult trees. Homogeneous cuttings, harvested in May or June, rooted in alveolated plates in the nursery, were supplied to INRA Sophia Antipolis (France) in December. Cuttings were repotted individually into 15-liter containers filled with a sandy substrate (70\% sand), together with a five-leaf tomato plantlet previously grown in a 400-ml plastic container. The containers were arranged in a completely randomized block design in early February, on iron benches in the greenhouse. Three weeks later, in March, the tomato plant in each container was inoculated with 2,500 24- to 72-h-old infective second-stage juveniles, which were placed in four holes, $3 \mathrm{~cm}$ deep and $3 \mathrm{~cm}$ from the stem. There were four replicates (= rooted cuttings) per Prunus accession in experiment 1 and two replicates in experiment 2 . In all experiments, the aerial parts of the tomato plants were cut off and removed 3 months after inoculation. New nematode-free five-leaf tomato plants were then transferred singly into each container and also grown for a new cycle of 3 months (Fig. 2). A further 6 (experiment 1) or 14 (experiment 2) additional tomato growth cycles were carried out in the same way.

Plants were grown in a glasshouse, with daily drip irrigation, and were fertilized weekly with an $\mathrm{N}-\mathrm{P}_{2} \mathrm{O}_{5}-\mathrm{K}_{2} \mathrm{O}$ nutrient solution supplemented with complete trace elements. The plants were placed in conditions suitable for Prunus spp. development over several years, with natural light and maintenance of the temperature between $10^{\circ} \mathrm{C}$ (to fulfill chilling requirements during winter nights) and $35^{\circ} \mathrm{C}$ (to prevent summer plant dormancy). These near-optimal conditions, mimicking natural growth conditions in the Mediterranean Basin, resulted in a short winter leaf fall and dormancy.

Final evaluations. At the end of the final cycle (the 7 th for experiment 1 and the 15 th for experiment 2$), \approx 21(7 \times 3$, for experiment 1$)$ or $\approx 45(15 \times 3$, experiment 2$)$ months after Prunus planting, the tomato root systems in each container were carefully separated from the soil and from Prunus roots, and RKN attacks were rated with a root gall index $(\mathrm{GI})$, according to the six-point $(0$ to 5$)$ scale of Barker (2) $(0=$ no gall and $1=1$ to $10,2=11$ to

TABLE 1. Characteristics of the experiments and of the plant and nematode materials used ${ }^{z}$

\begin{tabular}{|c|c|c|c|}
\hline Plant accessions & Resistance genes & Duration & Meloidogyne incognita isolates \\
\hline \multicolumn{4}{|l|}{ Experiment 1} \\
\hline Subexperiment $1 \mathrm{a}$ (4 replicates) & & 2 years & 'Morelos' and 'Kursk' \\
\hline Myrobalan plum 'P.2175' & Mal (heterozygous) & A single crop for 2 years & $\ldots$ \\
\hline Piersol & $M i-1$ & ... & $\cdots$ \\
\hline St Pierre & No gene & $\ldots$ & $\cdots$ \\
\hline Subexperiment $1 \mathrm{~b}$ & As for $1 \mathrm{a}$ & As for $1 \mathrm{a}$ & As for $1 \mathrm{a}$ \\
\hline Experiment 2 (2 replicates) & $\ldots$ & 4 years & Kursk \\
\hline$(\mathrm{P} .2175 \times \mathrm{GN} 22)_{43}$ & $M a l+R M i a$ & $\ldots$ & $\ldots$ \\
\hline$(\mathrm{P} .2175 \times \mathrm{GN} 22)_{66}$ & RMia & $\ldots$ & $\ldots$ \\
\hline$(\mathrm{P} .2175 \times \mathrm{GN} 22)_{81}$ & No gene & $\ldots$ & $\ldots$ \\
\hline Reference tomato material & & 15 growth cycles of 3 months & $\ldots$ \\
\hline Piersol & $M i-1$ & $\ldots$ & $\ldots$ \\
\hline St Pierre & No gene & $\ldots$ & $\ldots$ \\
\hline
\end{tabular}

${ }^{\mathrm{z}}$ Experiment 1 was divided into two successive subexperiments (a and b). Experiment 2 was performed after experiment 1. 
$30,3=31$ to $70,4=71$ to 90 , and $5>90 \%$ of root system galled) but with the addition of intermediate steps (0.5-point increases) to provide a more precise evaluation of the galling observed. The RKN-S Prunus plants and the R-gene-carrying Prunus plants were then processed differently. In containers of R Prunus plants, the Prunus root systems and soil were carefully extracted, intact, from the container. This whole root + soil system was divided into sectors and each sector was analyzed rigorously by the observation, with a binocular microscope, of the mother roots and their secondary roots and rootlets in a linear fashion for the detection of any swellings potentially due to RKNs ("nematode galls"). When a swelling resembling a nematode gall was observed, the small fragment of rootlet carrying the swelling was isolated in a petri dish, gently washed free of any adhering soil, and then dissected for observation of the putative fixed nematode stages (third and fourth developmental stages, female adults). Because we aimed to select virulent individuals able to overcome the $R$ genes, we avoided the use of nematode-staining chemicals, which may be toxic. Putative Prunus-virulent nematodes were rescued as follows, in a biological test. The root pieces and root debris from the dissected fragment containing the gall were recovered and embedded among the dense rootlets of a three-leaf RKN-S St Pierre (lacking $\mathrm{Mi}-1$ ) tomato plantlet grown in a 250 -ml container in a growth chamber at $25^{\circ} \mathrm{C}$ ( $16 \mathrm{~h}$ of light and $8 \mathrm{~h}$ of darkness). RKN attacks in the 250-ml tomato containers inoculated with isolated galls were assessed after 3 months (i.e., more than two complete nematode cycles). In containers of RKN-S Prunus plants, the plants were carefully extracted and washed and we then checked for the presence of egg masses in the galls under a binocular microscope. The complete root system was scored with the GI rating system described above (score of 0 to 5).
Comparison of the durability of resistance in Prunus spp. and tomato. In both experiments 1 and 2, we compared the durability of resistance conferred by the Prunus $R$ genes with that conferred by the tomato $M i-1$ gene, as follows. We grew single plants of the tomato Piersol (carrying $M i$ - 1 ) in 15-liter containers, together with single plants of the $\mathrm{S}$ tomato St Pierre (lacking $\mathrm{Mi}$ 1). The St Pierre tomato plants in each container were inoculated as described above for Prunus spp. (Fig. 2). The subsequent steps were also identical to those for Prunus spp. (7 or 15 successive total cycles of 3 months each for experiments 1 and 2, respectively). However, at the end of each tomato growth cycle, the aerial parts of both the $\mathrm{R}$ and $\mathrm{S}$ plants were cut and removed and new plants of the two cultivars were planted for the next growth cycle. At the end of each experiment, statistical analyses of GI ratings were carried out using analysis of variance (XL STAT 2011; Addinsoft SARL, Paris). Mean GI data were compared by Fisher's least significant difference multiple-range test, considering values of $\mathrm{P}<0.05$ to be significant (39).

DNA extraction and polymerase chain reaction marker analysis. Prunus genomic DNA was extracted from frozen leaves, with a modified version of the procedure described by SaghaiMaroof et al. (46). The intragenic codominant sequence-characterized amplified region marker NSCAFLP2 was used to confirm the presence of $M a$ ( $M a l$ allele carried by the accession P.2175) (13) and the dominant marker SSR9 was used to confirm the presence of RMia $\left(R M i a_{\text {Nem }}\right.$ allele carried by the accession Nemared) (D. Esmenjaud, unpublished data) (Fig. 1). The polymerase chain reaction fragments were size fractionated by electrophoresis in a $1.5 \%$ agarose gel in $1 \times$ Tris-acetate-EDTA running buffer, with 100-bp molecular-weight markers (Life Technologies, Saint Aubin, France).

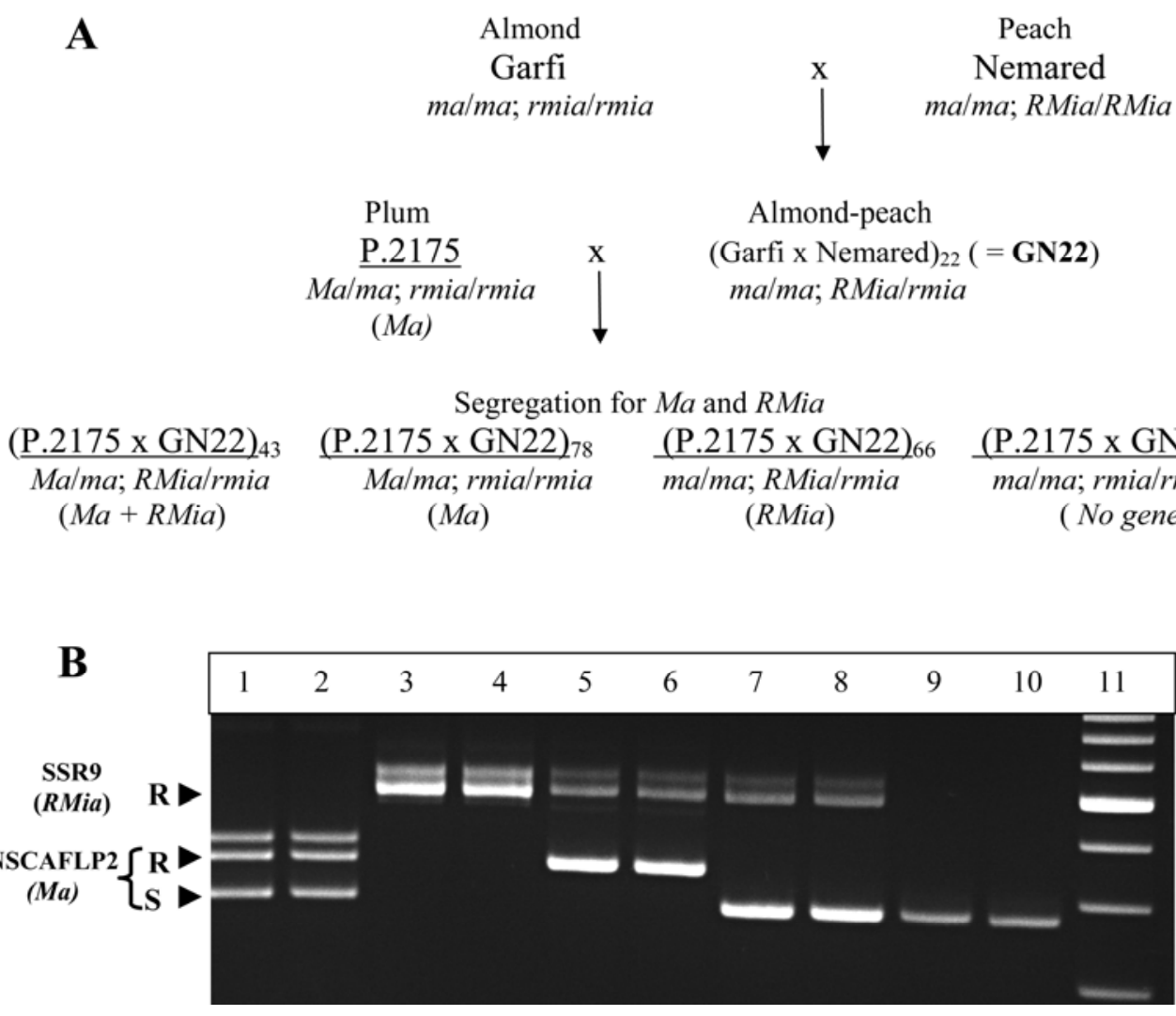

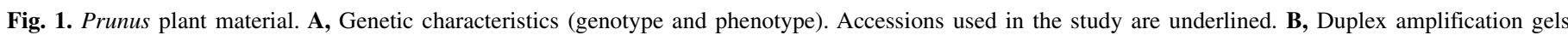

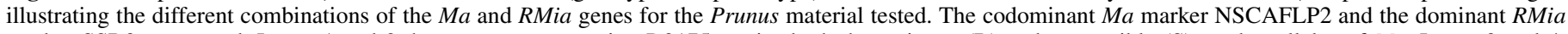

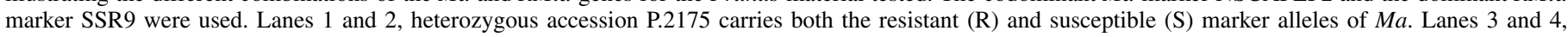

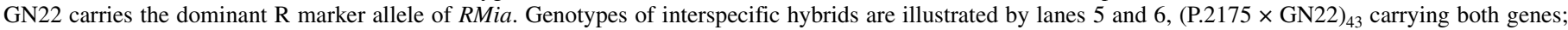

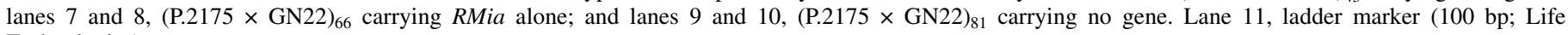
Technologies). 


\section{RESULTS}

Attempts to select virulent nematodes in pure Myrobalan plum. Durability was evaluated in the pure Myrobalan plum background of clonal accession P.2175 during the first 4 years of the study (experiment 1, divided into two successive 2-year evaluations: subexperiments 1a and 1b). As expected, galling levels in $\mathrm{S}$ tomato (St Pierre) cultivated with Prunus spp. or $\mathrm{R}$ tomato plants were high $(\mathrm{GI} \geq 4)$ and numerous females and egg masses were observed, regardless of the RKN isolate. Galling levels were slightly (but not significantly) higher in the Morelos isolate than in Kursk (Table 2).

Ma-carrying P.2175 plum. No RKN galls were observed on accession P.2175 in either of the subexperiments, regardless of the isolate used. Very few incipient galls (no more than four per complete root system) were detected; the pieces of rootlet harboring these incipient galls were dissected but no swollen RKN stages were seen. The pieces of tissue collected that had been placed in the close vicinity of RKN-S tomato rootlets (one tomato plant per Prunus plant) for observation caused no nematode multiplication and, consequently, no $M a$-virulent nematodes were recovered after 3 months.

Mi-1-carrying reference tomato. In the Piersol $\mathrm{R}$ tomato, galling was observed for both RKN isolates, regardless of the subexperiment considered. In subexperiment 1a, galling index obtained was higher for Morelos than for Kursk (although this difference was not significant due to the considerable variability of the data), and galling and the corresponding development of virulent individuals were observed for all but one of the Piersol plants (the exception was inoculated with Kursk). In subexperiment $1 \mathrm{~b}$, similar levels of galling were observed for both isolates and virulent nematodes were observed in all Piersol plants, regardless of the isolate used.

Attempts to select virulent nematodes in the interspecific Myrobalan $\times$ Amygdalus background. Resistance durability was assessed over a period of 4 years in four siblings of the P. $2175 \times$ GN22 progeny, each corresponding to one of the four possible combinations of the $M a$ and RMia genes (Table 3). This experiment was carried out with the Morelos isolate, which was identified as the most aggressive.

Prunus accessions carrying the Ma or RMia genes. Galling in S tomato (St Pierre) grown with the Prunus plants was regular and high $(\mathrm{GI}=4.5)$. Replicates of S $(\mathrm{P} .2175 \times \mathrm{GN} 22)_{81}$ plants, lacking both genes, declined in health during the first year and died during the second year of the experiment, as a consequence of severe nematode attacks. The entire root systems of these plants were galled and they harbored numerous females with egg masses. Other individuals-(P.2175 $\times$ GN22) 78 (carrying $M a$ alone), $(\mathrm{P} .2175 \times \mathrm{GN} 22)_{43}$ (carrying Ma+ RMia), and (P.2175 $\times$ GN22) $)_{66}$ (carrying RMia alone)-behaved in a similar manner, all remaining gall-free for the full 4 years of the experiment. Rootlet fragments with incipient galls were less numerous than in the Myrobalan plum P.2175, presumably because the interspecific material had less creeping rootlets than pure plum. Our data also confirmed the result of the histological study of the effects of the $M a$ gene by Khallouk et al. (30) in both Myrobalan plum P.2175 and interspecific material P.2175 $\times \mathrm{GN}$, in which the authors observed the induction of new subterminal lateral rootlets, which replaced the damaged terminal apices (data not shown). Rootlet fragments showing putative nematode galls were retrieved for observation under a binocular microscope and then placed in the close vicinity of the roots of the host tomato St Pierre. No virulent

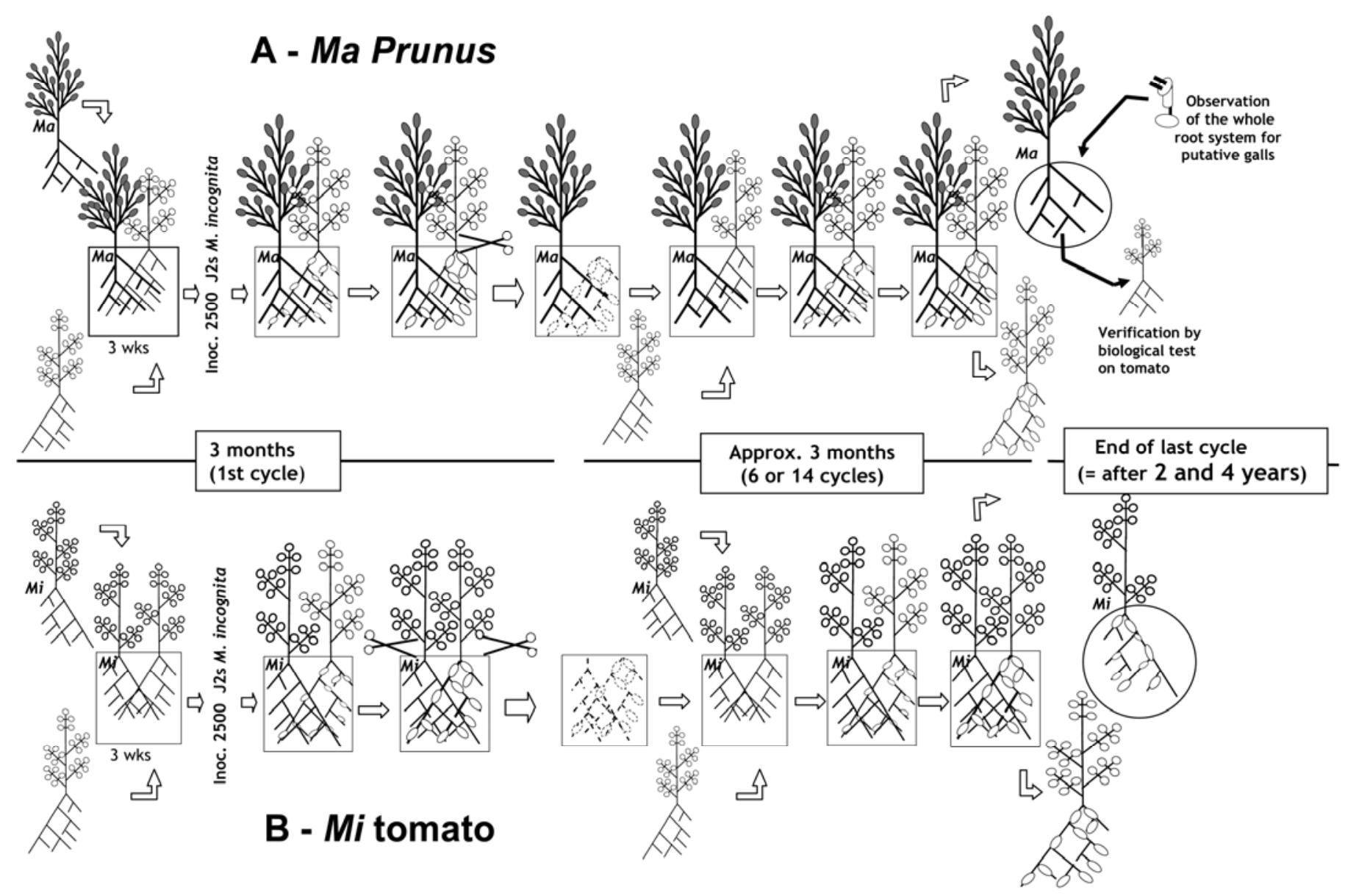

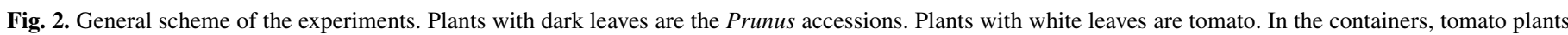
lacking Mi-1 ('St Pierre') are shown on the right (A and B) and those carrying Mi-1 ('Piersol') are shown on the left (B). Experiments are described in the text. 
nematodes were obtained on these tomato plants, regardless of the Prunus R individual concerned.

Mi-1-carrying reference tomato. The mean galling levels in $\mathrm{St}$ Pierre tomato associated with the Morelos isolate (common to experiments 1 and 2) were high and similar $(\mathrm{GI}=4.5)$ to those in subexperiments $1 \mathrm{a}$ and $1 \mathrm{~b}$ (Table 2). Galling was observed in both plant replicates of Piersol tomato, although the first replicate had a mean GI of 2.5 whereas the second replicate displayed only light galling $(\mathrm{GI}=0.5)$. Adaptation of this isolate to Piersol was estimated by determining its GI rating after 4 years. This GI was similar to that in 2-year subexperiment 1a and lower than that in 2-year subexperiment $1 \mathrm{~b}$.

After the final gall rating in experiment 2, the galled roots of each Piersol plant were recovered, washed free of any adhering soil, cut into 2-cm pieces, and transferred to a 5-liter container filled with sterilized sandy substrate and a five-leaf nematode-free Piersol tomato, under controlled growth chamber conditions $\left(25^{\circ} \mathrm{C}, 16 \mathrm{~h}\right.$ of light and $8 \mathrm{~h}$ of darkness). Two months later, the aerial parts of the tomato plants were cut off and removed and a new five-leaf nematode-free Piersol tomato was planted in the container. In total, four successive 2-month cycles of Piersol tomato plant growth were thus carried out. By growing the $M i-1$ Piersol tomato alone, we confirmed the stability of galling and the subsequent virulence of the $M$. incognita individuals previously observed on Piersol when St Pierre and Piersol plants were grown in the same container. Finally, in experiment 2, as in experiment 1, the adaptation of virulent individuals on tomato plants carrying $M i-1$, through the growth of these plants with a tomato plant lacking this gene, was observed. This effect was less marked in experiment 2 than in experiment 1 , despite the longer duration of experiment 2.

\section{DISCUSSION}

When selecting for durable resistance, a source should be characterized in terms of both its level ("vertical component" in the terminology of Van der Plank [49]) and its spectrum ("horizontal component" in the terminology of Van der Plank [49]) of resistance. We have focused on the detection of durable resistance in perennial plant material (19). The first step in our assessment of the vertical component of resistance involved a resistance screening method in which a high-level and continuous inoculum pressure could be applied over a single vegetative growth period, from May or June to October or November. In this screening method (20), each Prunus plant, grown individually in a container, was inoculated by the transfer of one RKN-galled five-leaf tomato host plant and attached soil (inoculated 2 months previously) into the same container, the aerial parts of the tomato plant being removed on planting. With an initial inoculum of 500 second-stage juveniles (J2s), we estimated that 160,000 J2s + eggs per container were released in a single Prunus container over a period of 4 months. This procedure made it possible to screen for high levels of resistance during a complete vegetative growth cycle of the Prunus plant and proved efficient for the identification of genes conferring high levels of RKN-specific resistance in diverse sources $(23,24,50)$. In particular, it led to the identification of the $M a(21,22,34,45)$ and RMia $(12,24)$ genes considered in this study.

The method used here is complementary to that described above, because it made it possible to evaluate the durability of resistance over longer periods (2 to 4 years). Indeed, multiyear evaluations of the durability of the resistance conferred by the $M a$

TABLE 2. Comparison of attacks by two isolates of Meloidogyne incognita ('Morelos' and 'Kursk') from tomato interacting with a Myrobalan plum carrying the $M a$ gene and a tomato carrying the $M i-1$ gene $^{\mathrm{y}}$

\begin{tabular}{|c|c|c|c|c|}
\hline \multirow[b]{2}{*}{ Interaction $^{\mathrm{z}}$} & \multicolumn{2}{|c|}{ Subexperiment 1a (years 1-2) } & \multicolumn{2}{|c|}{ Subexperiment 1b (years 3-4) } \\
\hline & Morelos & Kursk & Morelos & Kursk \\
\hline \multicolumn{5}{|l|}{ Interaction with $\mathrm{Mal}$} \\
\hline Myrobalan plum P.2175 gall index & $0 \mathrm{a}$ & $0 \mathrm{a}$ & $0 \mathrm{a}$ & $0 \mathrm{a}$ \\
\hline Nematode multiplication in biological tests & None & None & None & None \\
\hline Tomato St Pierre gall index & $4.5(4.5) \mathrm{d}$ & $4.3(4.0-4.5) \mathrm{d}$ & $4.3(4.0-4.5) \mathrm{d}$ & $4.1(3.5-4.5) \mathrm{d}$ \\
\hline
\end{tabular}

TABLE 3. Final gall index ratings for the Meloidogyne incognita isolate 'Morelos' in the Mi-1-carrying tomato 'Piersol' grown with the susceptible tomato 'St Pierre' or in Prunus accessions carrying combinations of the Ma and RMia genes grown with the St Pierre tomato ${ }^{\mathrm{x}}$

\begin{tabular}{|c|c|c|c|}
\hline$\underline{\text { Plant accessions }}^{\mathrm{y}}$ & Gene $(\mathrm{s})$ & Prunus or tomato & Tomato, St Pierre \\
\hline \multicolumn{4}{|l|}{ Interspecific Prunus } \\
\hline$(\mathrm{P} .2175 \times \mathrm{GN} 22)_{78}$ gall index & Mal & $0 \mathrm{a}$ & \\
\hline Rootlet fragments with incipient putative RKN galls & $\ldots$ & $1.5(1-2)$ & $4.5(4.5-4.5) \mathrm{c}$ \\
\hline$(\mathrm{P} .2175 \times \mathrm{GN} 22)_{43}$ gall index & $M a 1+R M i a$ & $0 \mathrm{a}$ & \\
\hline Rootlet fragments with incipient putative RKN galls & $\ldots$ & $0.5(0-1)$ & $4.5(4.5-4.5) \mathrm{c}$ \\
\hline Nematode multiplication in a biological test & $\ldots$ & None & $\ldots$ \\
\hline$(\mathrm{P} .2175 \times \mathrm{GN} 22)_{66}$ gall index & RMia & $0 \mathrm{a}$ & 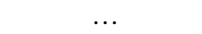 \\
\hline$(\mathrm{P} .2175 \times \mathrm{GN} 22)_{81}$ gall index & No gene & $4.3(4.0-4.5) \mathrm{c}^{\mathrm{z}}$ & $4.5(4.5-4.5) \mathrm{c}$ \\
\hline Tomato, St Pierre gall index & $M i-1$ & $1.5(0.5-2.5) b$ & $4.5(4.5-4.5) \mathrm{c}$ \\
\hline
\end{tabular}

${ }^{\mathrm{x}}$ Data shown are the means of two replicates, with individual values shown in parentheses. Gall index values followed by the same letter were not significantly different in Fisher's (least significant difference) multiple range tests, taking $P<0.05$ as significant.

${ }^{y}$ Gall index rating 0 to 5 , where $0=$ no galls and $1=1$ to $10 ; 2=11$ to $30 ; 3=31$ to $70 ; 4=71$ to $90 ; 5=>90 \%$ of root system galled. RKN $=$ root-knot nematode.

${ }^{z}$ Values shown are those for the end of the first year because both plants of this accession died during the second year. 
and RMia genes were carried out in glasshouse facilities providing light and temperature conditions suitable for both Prunus plant growth and nematode development on its tomato host plant. Natural seasonal variations of day length and the maintenance of low winter temperatures resulted in chilling, leading to the winter leaf fall and dormancy essential for the multiyear growth and development of Prunus spp.

Using two independent $M$. incognita isolates, we first evaluated, over a period of 2 years, the durability of the resistance conferred by the $M a$ gene in its original pure-plum background. No nematodes displaying virulence against the $M a$ gene were selected, whatever the isolate used, whereas galling and individuals virulent against the $M i-1$ gene were concomitantly observed on tomato. We increased the likelihood of selecting such $M a$-virulent individuals by increasing the nematode pressure on the $R$ gene. We did this, in experiment 2, by (i) using the most aggressive isolate, (ii) carrying out the experiment for twice as long (i.e., 4 years), and (iii) using plants with a hybrid genetic background associating plum and almond-peach, which is more susceptible to RKNs. This 4-year study of the resistance conferred by the $M a$ gene, either alone or together with RMia, in the interspecific background revealed that no virulent individuals were obtained with any of the gene combinations. Dissection of the very few incipient galls formed did not reveal the presence of swollen nematodes, ruling out the possibility that galling is linked to juveniles that have undergone the first few stages of development but have not completed the cycle, as reported by Malo (36), Meyer (37), and Nyczepir et al. (41) for M. javanica on the peach rootstock Nemaguard. On tomato carrying the $M i-1$ gene, we again observed galling and the generation of virulent RKN individuals from the same isolate. These results confirm the selection of $\mathrm{Mi}$-1-virulent individuals from an initially avirulent isolate and are entirely consistent with those of several authors describing natural $(48)$ or acquired virulence $(6,9,10)$ to this gene in $M$. incognita.

Thus, in our experimental conditions with $M$. incognita, we showed (i) an absence of RKN adaptation to the resistance conferred by $M a$ in the perennial backgrounds of both pure plum (Kursk and Morelos isolates) and interspecific Prunus material (Morelos only), (ii) an absence of adaptation to the resistance conferred by RMia in interspecific Prunus material (Morelos), and (iii) correlative successful adaptation to the resistance conferred by $\mathrm{Mi}-\mathrm{l}$ in the reference tomato plant (both isolates). In experiment 1 , the association of tomato cultivars with and without the $M i-1$ gene led to the selection of virulent individuals in each of two independent $M$. incognita isolates, within 2 years. Furthermore, in experiment 2 , despite expectations that the dilution of resistance factors and the increase in experiment duration from 2 to 4 years would favor the acquisition of virulence to $M a$ or RMia by the most aggressive isolate previously evaluated, no breakdown of genetic resistance in Prunus spp. was observed. However, over the same time period, this isolate adapted to the Mi-1-bearing tomato plants. Moreover, the growth of these Piersol tomato plants alone, in an additional experiment, resulted in similar levels of galling and confirmed that the $M$. incognita individuals observed previously on Piersol during the growth of St Pierre with Piersol had acquired a stable virulent status-a durable ability to reproduce on the $M i$ - 1 -carrying material.

In our study, we considered the resistance of the Prunus material as a whole and it would be necessary, for breeding purposes, to dissect this resistance out to determine what proportion was due to the effect of major genes (Ma or RMia) and what proportion was specific to the Prunus background (minor genes or quantitative trait loci). However, studies of the intrinsic effects of $R$ genes in the absence of the effect of the genetic environment are a real challenge in Prunus spp.

Current breeding approaches in Prunus spp. are based on maximizing resistance durability by pyramiding the Ma and RMia genes. Theoretically, pyramiding should greatly decrease the probability of resistance breakdown, because the two genes involved are probably associated with independent mechanisms of resistance and act in an additive fashion. In Solanaceous crops, the pepper $\mathrm{Mel} R$ gene controls all $\mathrm{Mi}$ - 1 -avirulent and $\mathrm{Mi}-\mathrm{I}$ virulent RKN isolates, whereas some of these isolates have overcome the pepper $M e 3 R$ gene (8). Mel also controls isolates virulent on plants carrying the $M e 3$ and $M e 7$ genes, indicating that nematode adaptation mechanisms are often specific to the $R$ gene on which selection occurred (17). These virulence specificity data are consistent with the hypothesized gene-for-gene relationship between the plant and the nematode (25). Virulence specificity is probably linked to the structure and function of the $R$ gene. In Prunus spp., $M a$ is a Toll interleukin-1 receptor nucleotide-binding site leucine-rich repeat gene (13) but the gene family to which RMia belongs has yet to be determined. The cloning of this gene would provide useful insight into this aspect. In the 'GF.557' rootstock, which carries a resistance allele of $R M i a$, and in P.2175, carrying $M a$, isolates of $M$. incognita artificially selected in the laboratory for their virulence against $\mathrm{Mi}-\mathrm{I}$ were unable to reproduce (22) and, thus, behaved like the avirulent, nonselected isolates from which they had been obtained.

Nevertheless, the durability of the resistance conferred by the $M a$ and RMia genes to $M$. incognita illustrated by our results must be put into perspective. A first key limitation of our data is linked to the genetics of the nematode pest. Our experiments were based on only one (experiment 2) or two (experiment 1) isolates of this RKN species. An isolate corresponds to the clonal descendants of a single female and thus consists entirely of isogenic individuals. Therefore, it cannot be considered representative of the genetic diversity of field populations that have undergone various processes of selection and are more likely to adapt to the selection pressures exerted by the plant genes. Another key point that must be considered is the time scale of the experiments, which ranged from only 2 to 4 years in this study, a very short period with respect to the 20- to 40-year lifespan of Prunus crops. Thus, for the confirmation and extension of these preliminary results obtained in a glasshouse, we are carrying out assays of the durability of the resistance conferred by the Ma and RMia genes, used alone or together, in field conditions in the Mediterranean region. This will confront rootstock materials, during the complete duration of the Prunus crop, with the natural genetic diversity of RKNs in conditions in which environmental factors may also vary considerably.

\section{ACKNOWLEDGMENTS}

We thank M. Kleinhentz and B. Lafargue (INRA-UREF, Bordeaux, France) for providing Prunus plant material.

\section{LITERATURE CITED}

1. Abad, P., Gouzy, J., Aury, J. M., Castagnone-Sereno, P., Danchin, E. G. J., Deleury, E., Perfus-Barbeoch, L., Anthouard, V., Artiguenave, F., Blok, V. C., et al. 2008. Genome sequence of the metazoan plant-parasitic nematode Meloidogyne incognita. Nat. Biotechnol. 26:909-915.

2. Barker, K. R. 1985. Design of greenhouse and microplot experiments for evaluation of plant resistance to nematodes. Pages 103-113 in: Plant Nematology Laboratory Manual. B. M. Zuckerman, W. F. Mai, and M. B. Harrison, eds. University of Massachusetts Agriculture Experiment Station, Amherst.

3. Brito, J., Powers, T. O., Mullin, P. G., Inserra, R. N., and Dickson, D. W. 2004. Morphological and molecular characterization of Meloidogyne mayaguensis isolates from Florida. J. Nematol. 36:232-240.

4. Brito, J. A., Stanley, J. D., Kaur, R., Cetintas, R., Di Vito, M., Thies, J. A., and Dickson, D. W. 2007. Effects of the Mi-1, $N$ and Tabasco genes on infection and reproduction of Meloidogyne mayaguensis on tomato and pepper genotypes. J. Nematol. 39:327-332.

5. Brito, J. A., Stanley, J. D., Mendes, M. L., Cetintas, R., and Dickson, D. W. 2007. Host status of selected cultivated plants to Meloidogyne mayaguensis in Florida. Nematropica 37:65-71. 
6. Castagnone-Sereno, P. 2002. Genetic variability of nematodes: A threat to the durability of plant resistance genes? Euphytica 124:193-199.

7. Castagnone-Sereno, P. 2012. Meloidogyne enterolobii (=M. mayaguensis): Profile of an emerging, highly pathogenic, root-knot nematode species. Nematology 14:133-138.

8. Castagnone-Sereno, P., Bongiovanni, M., and Djian-Caporalino, C. 2001. New data on the specificity of the root-knot nematode resistance genes $\mathrm{Mel}$ and $\mathrm{Me} 3$ in pepper. Plant Breed. 120:429-433.

9. Castagnone-Sereno, P., Bongiovanni, M., Palloix, A., and Dalmasso, A. 1996. Selection for Meloidogyne incognita virulence against resistance genes from tomato and pepper and specificity of the virulence/resistance determinants. Eur. J. Plant Pathol. 102:585-590.

10. Castagnone-Sereno, P., Semblat, J. P., and Castagnone, C. 2009. Modular architecture and evolution of the map-1 gene family in the root-knot nematode Meloidogyne incognita. Mol. Genet. Genomics 282:547-554.

11. Cetintas, R., Kaur, R., Brito, J. A., Mendes, M. L., Nyczepir, A. P., and Dickson, D. W. 2007. Pathogenicity and reproductive potential of Meloidogyne mayaguensis and $M$. floridensis compared with three common Meloidogyne spp. Nematropica 37:21-31.

12. Claverie, M., Bosselut, N., Lecouls, A. C., Voisin, R., Lafargue, B., Dirlewanger, E., Kleinhentz, M., Lafargue, B., Laigret, F., and Esmenjaud, D. 2004. Location of independent root-knot nematode resistance genes in plum and peach. Theor. Appl. Genet. 108:765-773.

13. Claverie, M., Dirlewanger, E., Bosselut, N., Van Ghelder, C., Voisin, R., Kleinhentz, M., Lafargue, B., Abad, P., Rosso, M. N., Chalhoub, B., and Esmenjaud, D. 2011. The Ma gene for complete-spectrum resistance to Meloidogyne species in Prunus is a TNL with a huge repeated C-terminal post-LRR region. Plant Physiol. 156:779-792.

14. Claverie, M., Dirlewanger, E., Cosson, P., Bosselut, N., Lecouls, A. C., Voisin, R., Kleinhentz, M., Lafargue, B., Caboche, M., Chalhoub, B., and Esmenjaud, D. 2004. High-resolution mapping and chromosome landing at the root-knot nematode resistance locus $M a$ from Myrobalan plum using a large-insert BAC DNA library. Theor. Appl. Genet. 109:13181327

15. Cook, R., and Evans, K. 1987. Resistance and tolerance. Pages 179-231 in: Principles and Practice of Nematode Control in Crops. R. H. Brown and B. R. Kerry, eds. Academic Press, Sydney, Australia.

16. Dirlewanger, E., Cosson, P., Howad, W., Capdeville, G., Bosselut, N., Claverie, M., Voisin, R., Poizat, C., Lafargue, B., Baron, O., Laigret, F., Kleinhentz, M., Arús, P., and Esmenjaud, D. 2004. Microsatellite genetic linkage maps of myrobalan plum and an almond-peach hybrid-location of root-knot nematode resistance genes. Theor. Appl. Genet. 109:827-838.

17. Djian-Caporalino, C., Molinari, S., Palloix, A., Ciancio, A., Fazari, A., Marteu, N., Ris, N., and Castagnone-Sereno, P. 2011. The reproductive potential of the root-knot nematode Meloidogyne incognita is affected by selection for virulence against major resistance genes from tomato and pepper. Eur. J. Plant Pathol. 131:431-440.

18. Esmenjaud, D. 2004. Breeding for durable resistance to root-knot nematodes in perennials: a European initiative for Prunus rootstocks. Pages 279-287 in: Nematology Monographs and Perspectives. Proc. IVth Int. Cong. Nematol. R. Cook, and D. J. Hunt, eds. Brill, Leiden, The Netherlands.

19. Esmenjaud, D., La Massese, C. S., Salesses, G., Minot, J. C., and Voisin, R. 1992. Method and criteria to evaluate resistance to Meloidogyne arenaria in Prunus cerasifera Ehr. Fundam. Appl. Nematol. 15:385-389.

20. Esmenjaud, D., Minot, J. C., and Voisin, R. 1996. Effects of durable inoculum pressure and high temperature on root galling, nematode numbers and survival of Myrobalan plum genotypes (Prunus cerasifera Ehr) highly resistant to Meloidogyne spp. Fundam. Appl. Nematol. 19:85-90.

21. Esmenjaud, D., Minot, J. C., Voisin, R., Bonnet, A., and Salesses, G. 1996. Inheritance of resistance to the root-knot nematode Meloidogyne arenaria in Myrobalan plum. Theor. Appl. Genet. 92:873-879.

22. Esmenjaud, D., Minot, J. C., Voisin, R., Pinochet, J., and Salesses, G. 1994. Interspecific and intraspecific resistance variability in Myrobalan plum, peach, and peach almond rootstocks using 22 root-knot nematode populations. J. Am. Soc. Hortic. Sci. 119:94-100.

23. Esmenjaud, D., Minot, J. C., Voisin, R., Pinochet, J., Simard, M. H., and Salesses, G. 1997. Differential response to root-knot nematodes in Prunus species and correlative genetic implications. J. Nematol. 29:370-380.

24. Esmenjaud, D., Voisin, R., Van Ghelder, C., Bosselut, N., Lafargue, B., Di Vito, M., Dirlewanger, E., Poëssel, J. L., and Kleinhentz, M. 2009. Genetic dissection of resistance to root-knot nematodes Meloidogyne spp. in plum, peach, almond, and apricot from various segregating interspecific Prunus progenies. Tree Genet. Genomes 5:279-289.

25. Flor, H. H. 1971. Current status of the gene-for-gene concept. Annu. Rev. Phytopathol. 9:275-296.

26. Handoo, Z. A., Nyczepir, A. P., Esmenjaud, D., van der Beek, J. G., Castagnone-Sereno, P., Carta, L. K., Skantar, A. M., and Higgins, J. A. 2004. Morphological, molecular, and differential-host characterization of Meloidogyne floridensis n. sp. (Nematoda: Meloidogynidae), a root-knot nematode parasitizing peach in Florida. J. Nematol. 36:20-35.

27. Hirschmann, H. 1986. Meloidogyne hispanica n. sp. (Nematoda, Meloidogynidae), the Seville root-knot nematode. J. Nematol. 18:520-532.

28. Janati, A., Bergé, J. B., Triantaphyllou, A. C., and Dalmasso, A. 1982. Nouvelles données sur l'utilisation des isoestérases pour l'identification des Meloidogyne. Rev. Nématol. 5:147-154.

29. Johnson, R. 1981. Durable resistance: Definition of, genetic control, and attainment in plant breeding. Phytopathology 71:567-568.

30. Khallouk, S., Voisin, R., Van Ghelder, C., Engler, G., Amiri, S., and Esmenjaud, D. 2011. Histological mechanisms of the resistance conferred by the Ma gene against Meloidogyne incognita in Prunus spp. Phytopathology 101:945-951.

31. Kiewnick, S., Dessimoz, M., and Franck, L. 2009. Effects of the $M i-1$ and the $N$ root-knot nematode-resistance gene on infection and reproduction of Meloidogyne enterolobii on tomato and pepper cultivars. J. Nematol. 41:134-139.

32. Kochba, J., and Spiegel-Roy, P. 1975. Inheritance of resistance to the rootknot nematode (Meloidogyne javanica Chitwood) in bitter almond progenies. Euphytica 24:453-457.

33. Laterrot, H. 1975. Séries de lignées isogéniques de tomate ne différant que par certains gènes de résistance aux maladies. Phytopathol. Mediterr. 14:129-130.

34. Lecouls, A. C., Salesses, G., Minot, J. C., Voisin, R., Bonnet, A., and Esmenjaud, D. 1997. Spectrum of the Ma genes for resistance to Meloidogyne spp. in Myrobalan plum. Theor. Appl. Genet. 95:1325-1334.

35. Lu, Z. X., Reighard, G. L., Nyczepir, A. P., Beckman, T. G., and Ramming, D. W. 2000. Inheritance of resistance to root-knot nematodes (Meloidogyne sp.) in Prunus rootstocks. HortScience 35:1344-1346.

36. Malo, S. E. 1967. Nature of resistance of 'Okinawa' and 'Nemaguard' peach to the root-knot nematode Meloidogyne javanica. Proc. Am. Soc. Hortic. Sci. 90:39-46.

37. Meyer, A. J. 1978. Why is 'Nemaguard' rootstock resistant to root-knot nematodes (Meloidogyne spp.) and 'Kakamas' susceptible? Decid. Fruit Grow. 28:66-72.

38. Milligan, S. B., Bodeau, J., Yaghoobi, J., Kaloshian, I., Zabel, P., and Williamson, V. M. 1998. The root knot nematode resistance gene $M i$ from tomato is a member of the leucine zipper, nucleotide binding, leucine-rich repeat family of plant genes. Plant Cell 10:1307-1319.

39. Noe, J. P. 1985. Analysis and interpretation of data from nematological experiments. Pages 187-196 in: An Advanced Treatise on Meloidogyne. K. R. Barker, C. C. Carter, and J. N. Sasser, eds. North Carolina State University Graphics, Raleigh.

40. Nyczepir, A., and Esmenjaud, D. 2007. Peach nematodes. Pages 505-535 in: The Peach: Botany, Production and Uses. D. R. Wayne, and D. Bassi, eds. CAB Editions, New York.

41. Nyczepir, A. P., Esmenjaud, D., and Eisenback, J. D. 1998. Pathogenicity of Meloidogyne sp. (FL-isolate) on Prunus in the southeastern United States and France. J. Nematol. 30:509.

42. Rammah, A., and Hirschmann, H. 1988. Meloidogyne mayaguensis $\mathrm{n}$. sp. (Meloidogynidae), a root-knot nematode from Puerto-Rico. J. Nematol. 20:58-69.

43. Ramming, D. W., and Tanner, O. 1983. Nemared peach rootstock. HortScience 18:376.

44. Roberts, P. A. 1995. Conceptual and practical aspects of variability in root-knot nematodes related host-plant resistance. Annu. Rev. Phytopathol. 33:199-221.

45. Rubio-Cabetas, M. J., Minot, J. C., Voisin, R., Esmenjaud, D., Salesses, G., and Bonnet, A. 1999. Resistance response of the $M a$ genes from 'Myrobalan' plum to Meloidogyne hapla and M. mayaguensis. HortScience 34:1266-1268.

46. Saghai-Maroof, M. A., Soliman, K. M., Jorgensen, R. A., and Allard, R. W. 1984. Ribosomal DNA spacer-length polymorphisms in barley: Mendelian inheritance, chromosomal location and population dynamics. Proc. Natl. Acad. Sci. USA 88:8014-8018.

47. Trudgill, D. L., and Blok, V. C. 2001. Apomictic, polyphagous root-knot nematodes: Exceptionally successful and damaging biotrophic root pathogens. Annu. Rev. Phytopathol. 39:53-77.

48. Tzortzakakis, E. A., Adam, M. A. M., Blok, V. C., Paraskevopoulos, C., and Bourtzis, K. 2005. Occurrence of resistance-breaking populations of root-knot nematodes on tomato in Greece. Eur. J. Plant Pathol. 113:101105.

49. Van der plank, J. E. 1963. Plant Diseases: Epidemics and Control. Academic Press, New York and London.

50. Van Ghelder, C., Lafargue, B., Dirlewanger. E., Ouassa, A., Voisin, R., Polidori, J., Kleinhentz, M., and Esmenjaud, D. 2010. Characterization of the RMja gene for resistance to root-knot nematodes in almond: Spectrum, location, and interest for Prunus breeding. Tree Genet. Genomes 6:503-511.

51. Voisin, R., Rubio-Cabetas, M. J., Minot, J. C., and Esmenjaud, D. 1999. Penetration, development and emigration of juveniles of the nematode 
Meloidogyne arenaria in Myrobalan plum (Prunus cerasifera) clones bearing the Ma resistance genes. Eur. J. Plant Pathol. 105:103-108.

52. Wehunt, E. J. 1972. Influence of temperature on infection of Meloidogyne incognita acrita on Nemaguard peach seedlings. Plant Dis. Rep. 56:305308.

53. Williamson, V. M. 1998. Root-knot nematode resistance genes in tomato and their potential for future use. Annu. Rev. Phytopathol. 36:277-293.
54. Williamson, V. M. 1999. Plant nematode resistance genes. Curr. Opin. Plant Biol. 2:327-331.

55. Williamson, V. M., and Kumar, A. 2006. Nematode resistance in plants: The battle underground. Trends Genet. 22:396-403.

56. Yang, B., and Eisenback, J. D. 1983. Meloidogyne enterolobii n. sp. (Meloidogynidae), a root-knot nematode parasitizing pacara earpot tree in China. J. Nematol. 15:381-391. 